\title{
Nonchromatographic method for acid sphingomyelinase in WBC lysate using modified Dole solvent
}

This article was published in the following Dove Press journal:

Research and Reports in Medicinal Chemistry

12 September 2012

Number of times this article has been viewed

\section{Mohammad Zouheir Habbal}

Department of Pathology and Laboratory Medicine, American University of Beirut Medical Center, Beirut, Lebanon
Correspondence: Mohammad Zouheir Habbal

Department of Pathology and Laboratory Medicine, American University of Beirut Medical Center, PO Box I I-0236,

Riad El Solh II 0-72020, Beirut, Lebanon

$\mathrm{Tel}+96$ | | 350000 ext 5220

Fax +96 II 370845

Emailmh03@aub.edu.lb
Purpose: To use a modified fluorometric method to measure white blood cell acid sphingomyelinase activity.

Methods: White blood cell lysates were prepared and used as a source of the enzyme. Two tubes were used for each assay, the second as a blank. In each, N-(NBD-Aminolauroyl)sphingomyelin dissolved in chloroform-methanol $(2: 1)$ was added and the organic solvent was removed by nitrogen gas. Acetate buffer, $1 \%$ Triton $^{\mathrm{TM}} \mathrm{X} 100$ solution, and sonicated protein (the reaction tube only) were added to the residue. The mixture in each was then incubated at $37^{\circ} \mathrm{C}$ for 2 hours, which was followed by the addition of buffer, Dole solvent, heptane, and sodium chloride solution. The sonicated protein was added to the blank tube and NBD-ceramide was extracted by vortex for 5 minutes and brief centrifugation at $3000 \mathrm{rpm}$. The intensity of fluorescence of the upper phase was determined in a fluorometer at an excitation wavelength of $465 \mathrm{~nm}$ and emission wavelength at $530 \mathrm{~nm}$.

Results: In 20 normal patients, the range of enzyme activity was 305-1008 pmol with a mean of 570 pmol. In a proven case of Niemann-Pick disease type A by molecular gene analysis, enzyme activity was undetectable.

Conclusion: The modified method is convenient in a biomedical genetics laboratory where a request for sphingomyelinase is very infrequent.

Keywords: acid sphingomyelinase, Niemann-Pick disease, fluorescent analysis, white blood cells

\section{Introduction}

Sphingomyelinases are a group of enzymes that hydrolyze sphingomyelin into phosphorylcholine and biologically-active ceramide and are intimately involved in sphingomyelin-ceramide signaling pathway. ${ }^{1}$ At least five different sphingomyelinases have been described that differ in intracellular localization, $\mathrm{pH}$ optima, and divalent cation requirement. ${ }^{2-6}$ The lysosomal acidic sphingomyelinase (EC 3.1.4.12) is deficient in types A and B Niemann-Pick disease and therefore the diagnosis of this lipid-storage disorder is confirmed by measuring the activity of this enzyme in cell lysates obtained from patients. ${ }^{7,8}$

Methods used for sphingomyelinase determination include radioactivity ${ }^{9}$ and colorimetry, ${ }^{10}$ but more recent fluorometric methods - by virtue of their sensitivity, high precision, and ease of performance - have gained popularity over others. Since both the substrate and the product of the reaction are fluorescent, they are separated by solvent extraction, ${ }^{11}$ thin-layer chromatography, ${ }^{12}$ or high-performance liquid chromatography. ${ }^{13}$ The unavailability of the pure and commercial resource 
of 11-(9-anthroyloxy) undecanoic acid derivative of sphingomyelin as a substrate, described in detail by Gatt et al, ${ }^{11}$ prompted the author to use other fluorescent derivatives, namely N-(NBD-Aminolauroyl)sphingomyelin as a substrate and N-(NBD-ceramide) as a product, both available at $>98 \%$ purity. These two compounds were obtained from SigmaAldrich Corporation (St Louis, MO).

\section{Methods}

Preliminary experiments showed that NBD-ceramide is not extracted from the acidic buffer solution by Dole solvent (isopropyl alcohol/heptane/sulfuric acid, $0.5 \mathrm{~mol} / \mathrm{L} ; 40 / 10 / 1$ by volume). Increasing the ionic strength of the buffer with sodium chloride enabled perfect separation of the substrate and product. Using equimolar amounts of both resulted in $<1 \%$ of the substrate displaced in the organic phase, while more than $95 \%$ of the product recovered in that phase.

White blood cell lysates were prepared according to Alexander et $\mathrm{al}^{14}$ and used as a source of the enzyme. Two tubes were used for each assay, the second as a blank. In each, 2500 pmol N-(NBD-Aminolauroyl)sphingomyelin dissolved in chloroform-methanol (2:1) was added and the organic solvent was removed by nitrogen gas. To the residue, $100 \mu \mathrm{L}$ acetate buffer $(250 \mathrm{mM}$ sodium acetate and $1 \mathrm{mM}$ ethylenediaminetetraacetic acid; $\mathrm{pH} 5.0), 25 \mu \mathrm{L} \mathrm{1 \%}$ Triton $^{\text {TM }}$ $\mathrm{X}-100$ solution, and $50 \mu \mathrm{g}$ sonicated protein (the reaction tube only) were added, and made up to $200 \mu \mathrm{L}$ with acetate buffer. The mixture in each was then incubated at $37^{\circ} \mathrm{C}$ for 2 hours, which was followed by the addition of $300 \mu \mathrm{L}$ buffer, $2.5 \mathrm{~mL}$ Dole solvent, $2 \mathrm{~mL}$ heptane, and $1.5 \mathrm{~mL}$ sodium chloride solution $(100 \mathrm{mg} / \mathrm{mL})$. The sonicated protein was added to the blank tube and NBD-ceramide was extracted by vortex for 5 minutes and brief centrifugation at $3000 \mathrm{rpm}$. The intensity of fluorescence of the upper phase $(2.5 \mathrm{~mL})$ was determined in a fluorometer at an excitation wavelength of $465 \mathrm{~nm}$ and emission wavelength at $530 \mathrm{~nm}$.
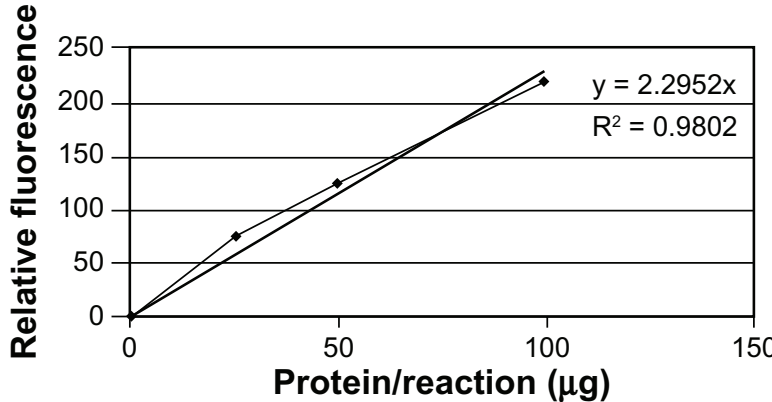

Figure I Effect of protein concentration on white blood cell enzyme activity.

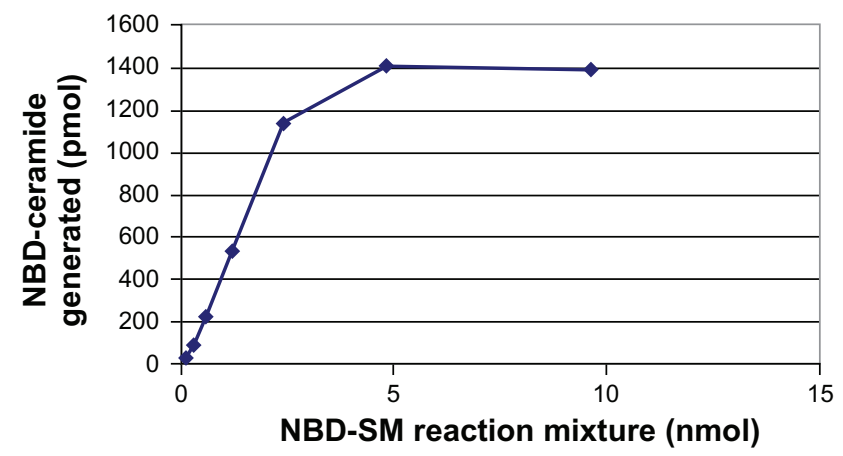

Figure 2 Effect of substrate concentration on white blood cell enzyme activity. Abbreviation: NBD-SM, N-(NBD-Aminolauroyl)sphingomyelin.

\section{Results}

Enzyme activity was calculated as NBD-ceramide/mg protein/hour (pmol) using a standard curve generated by adding defined amounts of NBD-ceramide to an identical assay mixture. The correlation coefficient $\left(\mathrm{r}^{2}\right)$ was 0.9996 and lower limit of detection was $4.06 \pm 0.27$ pmol.

The effect of protein concentration was studied by increasing the amounts of white blood cell sonicated protein. A linear relationship was obtained with $25-100 \mu \mathrm{g}$ protein $\left(r^{2}=0.9802\right.$; Figure 1).

The effect of substrate concentration was studied by increasing the amounts of $\mathrm{N}$-(NBD-Aminolauroyl) sphingomyelin using $100 \mu \mathrm{g}$ sonicated protein. A plot of NBD-ceramide (pmol) generated is shown in Figure 2.

In 20 normal patients, the range of enzyme activity was 305-1008 pmol with a mean of $570 \mathrm{pmol}$. In a proven case of Niemann-Pick disease type A by molecular gene analysis, enzyme activity was undetectable.

\section{Conclusion}

The modified method is convenient in a biomedical genetics laboratory where a request for sphingomyelinase is very infrequent, for example, in the author's laboratory. ${ }^{15}$

Although other sphingomyelinases are not involved in metabolic disorders as in the case of sphingomyelinase, it is tempting to speculate that those under right reaction conditions could also be detected and analyzed. This work is under investigation in the author's laboratory.

\section{Disclosure}

The author reports no conflicts of interest in this work.

\section{References}

1. Hannun YA. The sphingomyelin cycle and the second messenger function of ceramide. J Biol Chem. 1994;269(5):3125-3128. 
2. Yamanaka T, Hanada E, Suzuki K. Acid sphingomyelinase of human brain. Improved purification procedures and characterization. $J$ Biol Chem. 1981;256(8):3884-3889.

3. He X, Miranda SR, Xiong X, Dagan A, Gatt S, Schuchman EH Characterization of human acid sphingomyelinase purified from the media of overexpressing Chinese hamster ovary cells. Biochim Biophys Acta. 1999;1432(2):251-264.

4. Chattergee S, Ghosh N. Neutral sphingomyelinase from human urine. Purification and preparation of monospectic antibodies. J Biol Chem. 1989;264(21):12554-12561.

5. Bernardo K, Krut O, Wiegmann K, et al. Purification and characterization of magnesium-dependent neutral sphingomyelinase from bovine brain. J Biol Chem. 2000;275(11):7641-7647.

6. Duan RD, Nilsson A. Purification of a newly identified alkaline sphingomyelinase in human bile and effects of bile salts and phosphatidylcholine on enzyme activity. Hepatology. 1997;26(4):823-830.

7. Schneider PB, Kennedy EP. Sphingomyelinase in normal human spleens and in spleens from subjects with Niemann-Pick disease. J Lipid Res. 1967;8(3):202-209.

8. Harzer K, Benz HU. A simple sphingomyelinase determination for Niemann-Pick disease: differential diagnosis of types A, B and C. J Neurochem. 1973;21(4):999-1001.

9. Liu B, Hannun YA. Sphingomyelinase assay using radiolabeled substrate. Methods Enzymol. 2000;311:164-167.
10. Den Tandt WR, Jaeken J, Leroy JG, Eggermont E. A micromethod for sphingomyelinase assay using a chromagenic artificial substrate: its use in the diagnosis of Niemann-Pick disease. Acta Paediatr Belg. 1979; 32(4):253-258.

11. Gatt S, Dinur T, Barenholz Y. A fluorometric determination of sphingomyelinase by use of fluorescent derivatives of sphingomyelin, and its application to diagnosis of Niemann-Pick disease. Clin Chem. 1980;26(1):93-96.

12. Loidl A, Claus R, Deigner HP, Hermetter A. High-precision fluorescence assay for sphingomyelinase activity of isolated enzymes and cell lysates. $J$ Lipid Res. 2002;43(5):815-823.

13. He X, Chen F, Dagan A, Gatt S, Schuchman EH. A fluorescence-based, high-performance liquid chromatographic assay to determine acid sphingomyelinase activity and diagnose types A and B Niemann-Pick disease. Anal Biochem. 2003;314(1):116-120.

14. Alexander D, Dudin G, Talj F, et al. Five related Lebanese individuals with high plasma lysosomal hydrolases: a new defect in manose6-phosphate receptor recognition? Am J Hum Genet. 1984;36(5): 1001-1014.

15. American University of Beirut Medical Center. Pathology and lab medicine. Available from: http://labmed.aub.edu.lb/plm/800x600/ lbcg.htm. Accessed January 31, 2003.
Research and Reports in Medicinal Chemistry

\section{Publish your work in this journal}

Research and Reports in Medicinal Chemistry is an international, peerreviewed, open access journal publishing original research, reports, reviews and commentaries on all areas of medicinal chemistry. The manuscript management system is completely online and includes a very quick and fair peer-review system, which is all easy to use.

\section{Dovepress}

Visit http://www.dovepress.com/testimonials.php to read real quotes from published authors. 